Review Article

\title{
Three-Dimensional Bioreactor Technologies for the Cocultivation of Human Mesenchymal Stem/Stromal Cells and Beta Cells
}

\author{
Florian Petry, ${ }^{1}$ Tobias Weidner, ${ }^{1}$ Peter Czermak $\left(\mathbb{D},{ }^{1,2,3}\right.$ and Denise Salzig ${ }^{1}$ \\ ${ }^{1}$ Institute of Bioprocess Engineering and Pharmaceutical Technology, University of Applied Sciences Mittelhessen, Wiesenstraße 14, \\ 35390 Giessen, Germany \\ ${ }^{2}$ Department of Chemical Engineering, Kansas State University, Manhattan, KS, USA \\ ${ }^{3}$ Project Group Bioresources, Fraunhofer Institute for Molecular Biology and Applied Ecology (IME), Winchesterstr. 3, \\ 35394 Giessen, Germany
}

Correspondence should be addressed to Peter Czermak; peter.czermak@lse.thm.de

Received 29 September 2017; Accepted 31 December 2017; Published 14 March 2018

Academic Editor: Ioannis Papantoniou

Copyright (C) 2018 Florian Petry et al. This is an open access article distributed under the Creative Commons Attribution License, which permits unrestricted use, distribution, and reproduction in any medium, provided the original work is properly cited.

\begin{abstract}
Diabetes is a prominent health problem caused by the failure of pancreatic beta cells. One therapeutic approach is the transplantation of functional beta cells, but it is difficult to generate sufficient beta cells in vitro and to ensure these cells remain viable at the transplantation site. Beta cells suffer from hypoxia, undergo apoptosis, or are attacked by the host immune system. Human mesenchymal stem/stromal cells (hMSCs) can improve the functionality and survival of beta cells in vivo and in vitro due to direct cell contact or the secretion of trophic factors. Current cocultivation concepts with beta cells are simple and cannot exploit the favorable properties of hMSCs. Beta cells need a three-dimensional (3D) environment to function correctly, and the cocultivation setup is therefore more complex. This review discusses 3D cultivation forms (aggregates, capsules, and carriers) for hMSCs and beta cells and strategies for large-scale cultivation. We have determined process parameters that must be balanced and considered for the cocultivation of hMSCs and beta cells, and we present several bioreactor setups that are suitable for such an innovative cocultivation approach. Bioprocess engineering of the cocultivation processes is necessary to achieve successful beta cell therapy.
\end{abstract}

\section{Introduction}

There are an estimated 422 million diabetes patients worldwide, reflecting the growing prevalence of obesity, inactivity, stress, and smoking [1]. The clinical factor that ultimately links all diabetes patients is the failure of pancreatic beta cells. Most patients suffer from type-2 diabetes, which is initiated by insulin resistance in muscle and adipose tissue often beginning years before diabetes is diagnosed [2]. Insulin resistance leads to hyperinsulinemia, which combined with glucose toxicity enhances the dysfunction of the insulinproducing beta cells [3]. In contrast, type- 1 diabetes is innate and characterized by the selective autoimmune destruction of beta cells. Diabetes patients must control their blood glucose level very strictly and many need to inject insulin on a regular basis. Insulin injections are a significant burden for the patients and cannot imitate the precise control of blood glucose by functional beta cells, leading to acute and/or chronic complications. Therapeutic options that retain functional beta cell mass or prevent/reverse the degeneration of beta cell function would therefore be highly beneficial. Replacement strategies include the transplantation of whole human/porcine pancreatic islets, beta cell pseudoislets, or the application of islet progenitors derived from induced pluripotent stem cells (iPSCs) $[4,5]$. Several clinical phase I/II trials have demonstrated the safety and efficacy of transplanted islets and 
beta cell grafts [6] (https://www.clinicaltrials.gov/; condition/ disease: diabetes, other terms: beta cells, islets, biological; August 2, 2017, 15:13).

Most islet/beta cell replacement approaches face a number of challenges. First, there must be a guaranteed supply of suitable islets or beta cells. Like other transplantation types, the amount of donor tissue is often limited. One solution is an efficient expansion protocol for islets or beta cells, and another is the generation of islets from iPSCs or other stem cells. Although this addresses the scarcity of the resource, it does not solve the issue that beta cells in the transplanted grafts tend to undergo apoptosis due to the disrupted connection with the extracellular matrix (ECM) and inhospitable conditions at the transplantation site (e.g., hypoxia or missing vascularization). A further barrier for the long-term survival of transplanted cells is graft-versus-host disease (GVHD), fibrotic overgrowth due to the host inflammatory response, and in diabetic patients a general loss of immune system control. Cell death at the transplantation site can be addressed by helping beta cells to withstand the shock after transplantation. One such strategy for beta cells is cocultivation or cotransplantation with human mesenchymal stem/stromal cells (hMSCs), which play a key role in regenerative medicine and tissue engineering. The ability of hMSCs to modulate and suppress the immune system [7-12] could be particularly advantageous for the coapplication of beta cells (Figure 1). This ability is based on the secretion of large quantities of cytokines such as tumor necrosis factor alpha (TNF $\alpha$ ) and stanniocalcin-1 (STC-1) [13-15], communication with injured cells, and the resulting strong induction of downstream genes [14, 16, 17]. Lee et al. [18] observed that the administration of hMSCs (i.v.) to mice with a myocardial infarction improved cardiac function due to the expression of TNF $\alpha$-stimulated gene 6 protein (TSG-6). The antiinflammatory effect occurred when the injected hMSCs were kept as microemboli in the lung after $12-24 \mathrm{~h}$. Until this time, half of the hMSCs had already died. Therefore, the culture conditions and pretreatment of the cells could be important to enhance and accelerate the therapeutic effect [13]. In addition to TNF $\alpha$ and STC-1, hMSCs secrete other cytokines such as vascular endothelial growth factor (VEGF), hypoxiainducible factor 1-alpha (HIF-1 $\alpha$ ), and signaling molecules [19] which can strengthen beta cells and help them to survive at the transplantation site (Figure 1). To use the beneficial MSC effect in clinical practice, a 3D, high-cell-mass cocultivation of beta cells and MSCs is needed, because large numbers of functional cells are required for therapy $\left(10^{6}-10^{10}\right.$ cells per dose) [20]. Beta cells in particular lose most of their functionality in $2 \mathrm{D}$ cultures, because cultivation processes based on traditional monolayers in static tissue vessels do not mirror the complexity of the original tissue [21-23]. Monolayer cultures cannot provide mechanical stimulation and have limited cell-to-cell interactions and communication with ECM [21-24]. As an escape strategy, beta cells (and adherent eukaryotic cells in general) tend to form agglomerates in vitro to reconstitute the unique $3 \mathrm{D}$ environment in the body. Therefore, cell culture and tissue engineering should mimic the natural environment; that is, we must move away from flat monocultures and towards $3 \mathrm{D}$ cocultures. This opens the door for innovative bioreactor systems that enable the high-throughput manufacturing of cell agglomerates, spheroids, and organoids up to fully developed organs. Bioreactors create the microenvironment of the cells and offer the possibility to directly monitor and control it.

Here, we describe potential strategies to generate 3D cultures of beta cells, hMSCs, and also cocultures of both cell types. Based on what is now known about hMSC and beta cell cultivation in certain bioreactor systems, we discuss the challenges and parameters for cocultivation in a bioreactor, as well as bioreactor configurations suitable for the cocultivation of hMSCs and beta cells for high-cell-mass expansion or improved cell functionality.

\section{Three-Dimensional Cultivation Forms for hMSCs and Beta Cells}

A prerequisite for $3 \mathrm{D}$ bioreactor cultivation is the creation of a 3D cellular microenvironment. For hMSCs and beta cells, several cultivation forms are applicable and these are discussed below.

2.1. Cell Aggregation and Spheroid Formation. Beta cells originate from cell islets in the pancreas (islets of Langerhans) and have a strong tendency to agglomerate and form contacts via gap junctions and cell-adhesion molecules, such as cadherins [25]. Therefore, the reconstitution of the natural microenvironment in the form of spheroids helps beta cells to achieve high viability, rapid proliferation, a stable cell fate, a sufficient nutrient supply, and especially their function in glucose homeostasis $[25,26]$. Beta cells spontaneously aggregate when cultivated in vitro on a low-attachment surface with gentle movement. Amin et al. [27] produced beta cell spheroids in customized micromolds (384-well format) in a standard cell culture plate, achieving an output of 200,000 uniform spheroids with a diameter $<100 \mu \mathrm{m}$. The 2D- and 3D-expanded genetically modified beta cell line INS-1832/ 13 was superior in performance to reaggregated human islets, as indicated by the higher glucose-dependent stimulation index (SI) value for insulin. The cost of 3D cell cultures produced in this manner was not significantly higher than the cost of $2 \mathrm{D}$ cultures, and the cells can be expanded using standard reagents and protocols. It is important to control the size of the aggregates or spheroids because mass transport limitations cause aggregates larger than $200 \mu \mathrm{m}$ in diameter to be undersupplied in vitro $[26,28]$. Beta cells have a high oxygen demand, and oxygen transport within the aggregates occurs only by diffusion. Furthermore, hypoxic conditions are present at the transplantation site. The spheroids strongly promote angiogenesis and vasculogenesis, overcoming the limitations of mass transfer within cell aggregates at the transplantation site [29].

MSCs are usually expanded in 2D cultures in plastic vessels without losing their stem cell fate, but researchers have realized that such an environment alters the native phenotype of the MSCs [30-32]. Similar to beta cells, MSCs form clusters of 500-10,000 cells that define their own microenvironment, thus preserving and defining the MSC phenotype and the inherent properties of the cells [13, 21, 32, 33]. 


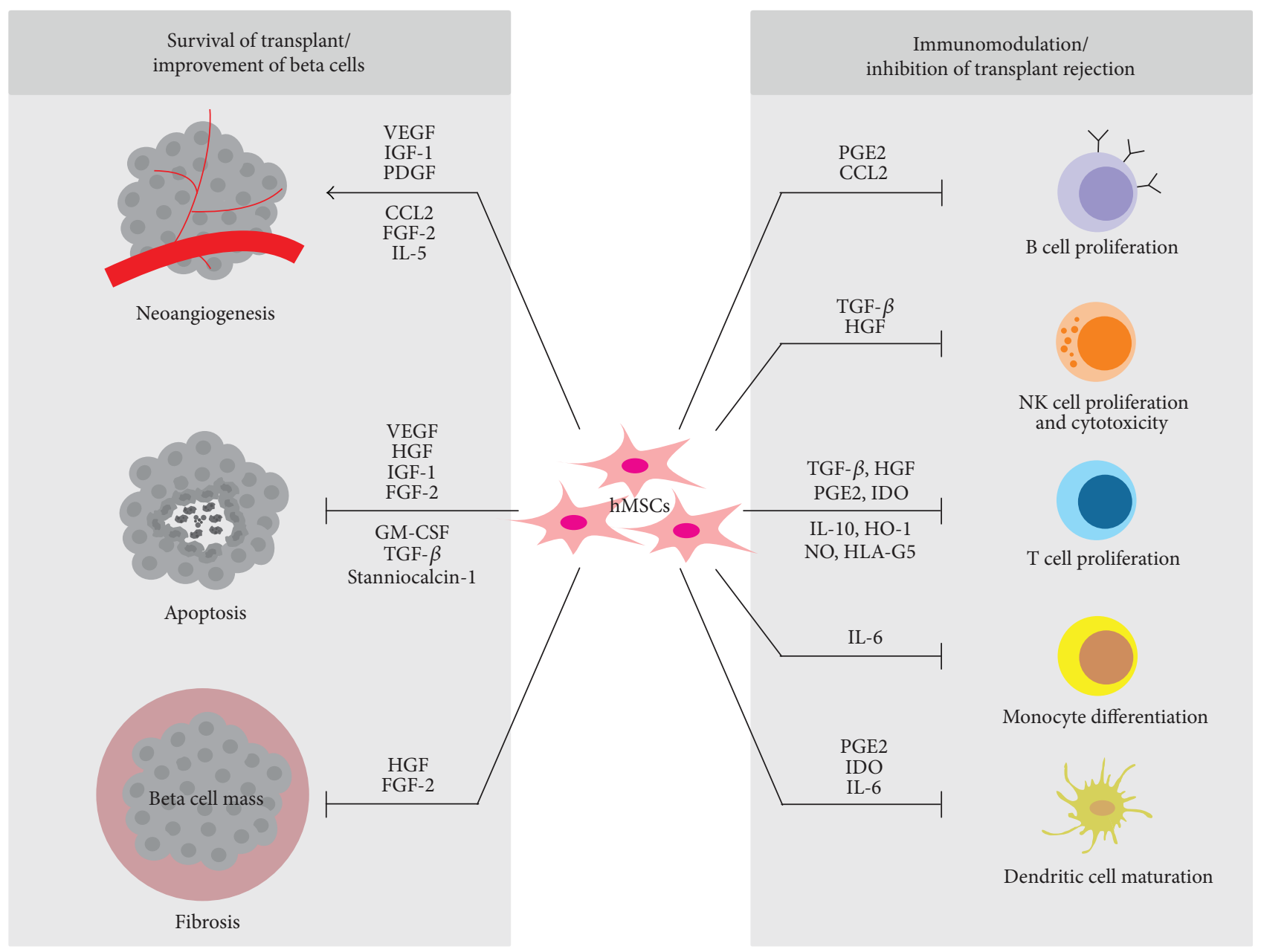

Figure 1: Therapeutic effect of human mesenchymal stem/stromal cells (hMSCs) in the context of beta cell engraftment. Human MSCs modulate the host immune systems, for example, by secreting various trophic factors. Therefore, they prevent rejection of allogenic beta cell grafts and improve the survival of the graft by promoting neoangiogenesis at the transplant site and prevent apoptosis and fibrosis. -1 inhibition, $\rightarrow$ improvement. Abbreviations: VEGF: vascular endothelial growth factor; IGF-1: insulin-like growth factor 1; PDGF: plateletderived growth factor; CCL2: monocyte chemoattractant protein-1; FGF-2: basic fibroblast growth factor; IL-5/6/10: interleukins 5, 6, and 10; HGF: hepatocyte growth factor; GM-CSF: granulocyte macrophage colony-stimulating factor; TGF- $\beta$ : transforming growth factor beta; PGE2: prostaglandin E2; IDO: indoleamine 2,3-dioxygenase; HO-1: heme oxygenase 1; NO: nitrogen monoxide; HLA-G5: human leukocyte antigen-G5.

Apoptosis in MSC spheroids depends on the spheroid size, cell number, and cultivation time. During the initial phase of spheroid formation, apoptosis/necrosis was rarely detected for agglomerates of 25,000 cells after $3 \mathrm{~d}$ [34]. Apoptosisregulating molecules like caspases, Notch, or interleukin-1 are triggered by the agglomeration and induce the production of TSG-6, STC-1, and other therapeutic molecules [13, 34-36]. Bartosh et al. [13] showed that hMSCs agglomerated using the hanging drop method express and secrete higher levels of TSG-6 than 2D-cultured hMSCs. Baraniak et al. [37] produced uniform cell spheroids by forced aggregation in a scaffold-free system. They used murine MSCs and seeded the cells at different densities in AggreWell $^{\mathrm{TM}}$ sixwell inserts to generate agglomerates by centrifugation. The self-assembly of cell aggregates in vitro and consequently the building of bridges between cells are facilitated by the mutual interaction of cadherin and integrin with proteins of the ECM $[32,38]$. The type of cadherin depends on the origin of the MSCs: in bone marrow-derived MSCs (BM MSCs), N-cadherin and cadherin-11 are preferentially expressed [32, 39], whereas E-cadherin is expressed most strongly in umbilical cord MSCs (UC MSCs) [32, 40]. The appearance of MSC aggregates is not constant and homogeneous: MSC spheroids undergo current changes and realignments based on their networking with the ECM, reflecting the levels of cadherin/integrin and cortical tension [32]. This behavior results in the development of rounded cells with low intracellular tension within cell aggregates and spreading cells with high intracellular tension on the outside $[32,41,42]$. The permanent rearrangement results in the compaction of the cell spheroids in vitro, as indicated by the decreasing diameter (from 630 to $350 \mu \mathrm{m})$ over 21 days [13, 32, 43].

Cellular behavior during the cocultivation of hMSCs and beta cells is even more dynamic, and the optimal conditions are not yet determined. MSCs can be cocultured directly with 
islets/beta cells, indirectly as feeder cells, or in a mixed mode. All these modes are beneficial for the islet/beta cells indicating that MSC-secreted factors are not enough to improve islet/beta cell quality, and direct cell-cell contact is also needed [44]. In direct coculture with intact islets, hMSCs attach mainly to the outside of the islets and did not penetrate them. The MSCs started to differentiate into progenitors of insulin-releasing cells. The indirect cocultivation of islets and MSCs had a positive effect on islet cell viability compared to monocultured intact islets and direct cocultured islets with MSCs. The survival rate of indirect cocultured islet was $60 \%$ after four weeks compared to $10 \%$ for monocultured and direct cocultured islets [45]. Long-term insulin immunostaining revealed high insulin expression in cocultured spheroids but little insulin in direct cocultured spheroids and monocultured islets. The expression of E-cadherin (a protein that may guide islet architecture and promote insulin secretion) was also higher. The glucose responsiveness (SI values) for the cocultured spheroids was higher than that for the monocultured islets [46]. Interesting phenomena occur when dispersed islet cells and MSCs are mixed and cultivated together. They initially formed an aggregate with an even distribution of both cell types, but after 3 days, the two populations started to separate. After 14 days, the separation of MSCs and islet cells was complete and all that remained was aggregated islets and spheroids. This demixing seemed to be cell-type dependent because a MSC-hepatocyte coculture remained intermixed [46]. It is not clear why beta cells show this behavior and whether it is reproducible with other MSC types or in other cultivation setups, but this result highlights the complexity of coculture setups and the importance of a tight control of the cellular environment. Environmental control can be achieved in bioreactors, but aggregated cells have the drawback that they are not protected against hydrodynamic stress in the bioreactor. Therefore, other cultivation forms are more advantageous for the cocultivation of hMSCs and beta cells in a bioreactor.

2.2. Cell Growth on Carriers. One suitable form of cultivation widely used in bioreactor systems is cell growth on carriers of different sizes, that is, microcarriers of $100-300 \mu \mathrm{m}$ and macrocarriers of $0.6-5 \mathrm{~mm}$. Carrier-based cultures are considered as a form of 3D cultivation, but nevertheless, the cells grow on flat or round substrates and the positive effect of aggregated cells is lost, so the term "pseudo-3D" is more appropriate. Microcarriers have been used for decades and come in porous and nonporous types. Porous microcarriers probably mimic $3 \mathrm{D}$ cell-cell interactions more accurately than nonporous microcarriers, but the surface of the latter can be modified to achieve some environmental influence, for example, by coating with collagen to enhance cell attachment or with laminin or vitronectin to change the surface charge [47]. All microcarrier types facilitate cell attachment and proliferation, but it remains a challenge to achieve high cell harvest yields without any harmful impact on the cells [48]. Therefore, the aim is to find a balance between efficient attachment/growth and high yields when the cells are harvested. Microcarriers offer a simple and efficient way to expand hMSCs and achieve clinically relevant numbers of cells with the required characteristics [19]. These psuedo$3 \mathrm{D}$ processes do not provide all the beneficial properties of 3D cultures but can generate hMSCs that show high vitality and a strong capacity to differentiate. Several microcarrier types have been shown to work for hMSC expansion, as reviewed in detail elsewhere $[49,50]$. Islet and beta cells have also been grown on microcarriers since the late 1980s [51]. Single human islets cells were successfully grown on nonporous Cytodex- 1 microcarriers for up to 8 days and showed stable insulin secretion [52]. Dispersed islet cells grown on macroporous CultiSpher-S carriers were highly viable and metabolically active, and the SI was $\sim 60 \%$ of that achieved by intact bovine islets within alginate microcapsules [53]. The investigation of a beta cell line growing on both carrier types confirmed efficient cell growth and improved insulin secretion compared to single cells and pseudoislets [54]. These studies showed that microcarriers not only facilitate the growth of hMSCs and/or beta cells but also improve their functionality. Microcarriers enable all forms of cocultivation (direct, indirect, and mixed) of hMSCs and beta cells. In direct cocultivation, both cell types are together added to the bioreactor and should distribute homogenously to the microcarriers. The indirect cocultivation includes two separate inoculation processes. First, each cell type is seeded to the suitable microcarrier type, and second, the two batches are combined. The advantage of this setup is the utilization of different microcarrier types adjusted to the specific cell requirements. The disadvantage is the fact that the cells cannot be separated completely. The cells are able to move/ migrate to different microcarriers called bead-to-bead transfer $[19,50]$. If a strict separation is needed, compartmentation has to be carried out in the cultivation setup, for example, by sieves/membranes (Figure 2). For both cocultivation strategies, the formation of large microcarrier agglomerations is unwanted, due to mass transfer limitations and a more difficult enzymatic harvest of the cells within the agglomerates. This problem of cell harvest must be solved and balanced for two cell types with different detachment behaviors and sensitivities to harvest conditions. For differentiation setups, a targeted clustering of cell-coated microcarriers to a kind of macrotissue can be done [55]. Here, mass transfer has to be balanced as well, but cell harvest must not be considered.

2.3. Encapsulation. Nonporous microcarriers cannot protect cells or provide a realistic 3D environment, whereas porous carriers tend to be more 3D-like, thus protecting cells by reducing shear stress. Encapsulation can do even more: cells are protected not only against hydrodynamic shear forces but also against the host immune system at the transplantation site. Encapsulation also maintains or improves cell functionality [56]. The encapsulation material strongly influences the cells and should ideally mimic the geometry, chemistry, and signaling environment of the natural ECM. The most common encapsulation materials are natural polymers, due to their biocompatibility and the mild polymerization conditions [56]. The current materials used in tissue engineering have been reviewed [22]. It is important to guarantee the exchange of secreted molecules, the exclusion of immune 

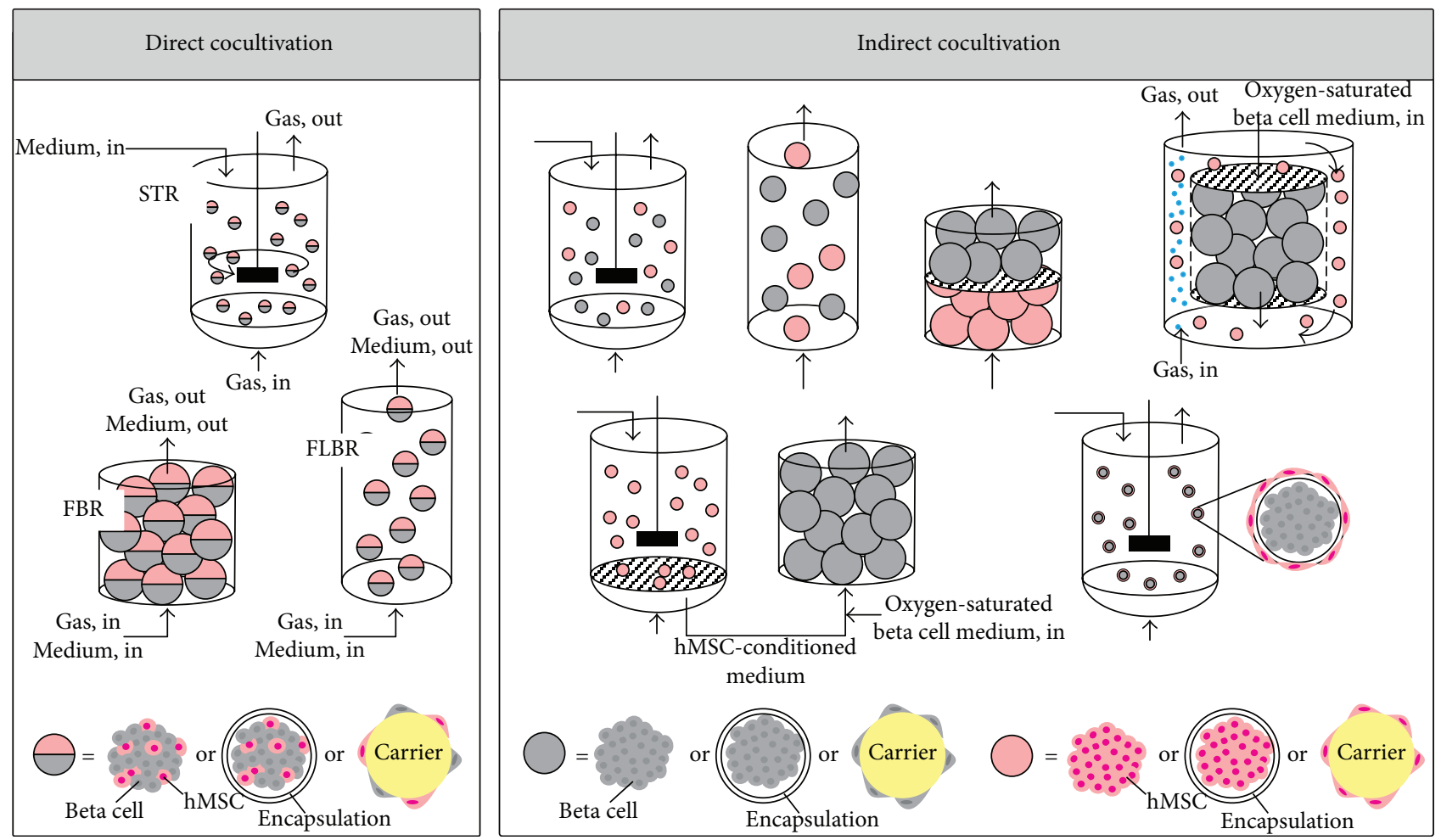

FIGURE 2: Bioreactor concepts for the cocultivation of human mesenchymal stem/stromal cells (hMSCs) and beta cells. Beta cells and hMSCs can be cocultivated using either a direct mode or an indirect mode. Therefore, the cells can be present as aggregates or as encapsulated cells or attached to a carrier. In direct cocultivation, one medium and one aeration rate must be chosen for both cells, whereas indirect cocultivation allows each cell type to be supplied with a cell-specific medium and aeration rate. Abbreviations: STR: stirred tank reactor; FBR: fixed-bed reactor; FLBR: fluidized-bed reactor.

system cells/components, the secure entrapment of the encapsulated cells, and a sufficient nutrient supply. The permeability and concentration of the matrix material influence the rate of diffusion, whereas the capsule size and additional membrane coatings determine whether nutrients are transported through the matrix to reach the cells. These factors must be adjusted depending on the nutrients required by the encapsulated cells. In the case of encapsulated spheroids, the major mass transport limitation is determined by the spheroid itself and the matrix permeability can be ignored [56, 57].

In the vast majority of islet transplantation and cultivation approaches, alginate has been used as the encapsulation material [58]. Alginate modifications that cause less foreignbody reactivity have promoted interest in alginate microencapsulation [59]. Alginate encapsulation has a positive impact on beta cells and hMSCs. For example, the encapsulation of pseudoislets in alginate or collagen-alginate increased cell viability and improved functionality compared to nonencapsulated islets in vitro and in vivo [26]. Furthermore, hMSCs have also been successfully cultivated in alginate capsules, often to achieve a desirable form of differentiation [60]. The mechanical and surface properties of the encapsulation material influence the organization, function, and proliferation of hMSCs, as well as their secretion of trophic factors and their multilineage potential $[61,62]$. The maintenance of undifferentiated and highly proliferative hMSCs in alginate capsules is important for their use as support cells for islets/ beta cells. Encapsulation alone positively influenced the hMSC secretome compared to monolayer cultures, by promoting the release of anti-inflammatory factors such as the key inflammatory mediator prostaglandin E2 [63]. However, it is uncertain whether the changes in the secretome reflect the $3 \mathrm{D}$ environment or the encapsulation material itself. The constant and regulated release of MSC-secreted factors indicates that encapsulation methods should be suitable for the treatment of metabolic disorders such as diabetes [56]. In coencapsulation experiments involving hMSCs and islets in alginate, the viability of the islets did not increase but the SI value increased compared to encapsulated islets alone [64]. These studies showed that encapsulation improves the functionality of hMSCs and beta cells and provides a useful cocultivation strategy in a bioreactor system.

\section{Bioreactor Technologies for the 3D Cultivation of MSCs}

The cultivation of hMSCs in a bioreactor has two main objectives: cell expansion and improved cell functionality. Bioreactor systems are needed to generate enough cells with the required properties, because many cells are required for each treatment $\left(0.4-10 \cdot 10^{6} \mathrm{MSCs} / \mathrm{kg}\right.$ body weight, depending on the disease and type of application [65]). Bioreactors achieve efficient cell expansion by monitoring important parameters 
such as substrate consumption/metabolite production, cell growth, and differentiation and by allowing the tight control of $\mathrm{pH}$, temperature, and gas supply. MSCs can lose their capacity for self-renewal or differentiate and subsequently lose their multipotency [37, 66-68]. Therefore, the regulation of the microenvironment is a challenging obstacle for bioreactor technologies $[33,61]$. In dynamic bioreactor systems, the cellular microenvironment is further influenced by fluid dynamics, which prevent the accumulation of secreted biomolecules, and shear stress can induce either desirable or undesirable forms of differentiation $[69,70]$. However, a controlled bioreactor system offers the chance to specifically influence the hMSC secretome and improve the resulting therapeutic effect. An investigation of the impact of dynamic cultivation on the hMSC secretome revealed the upregulation of classical trophic factors such as BDNF, NGF, VEGF, and IGF-1, which were important for the hMSC effect [71]. This highlights the impact of culture conditions on cell functionality. The main conditions required to grow MSCs in bioreactors include a large surface area to volume ratio, a closed system, automated inoculation and harvesting, and the automated online control of culture parameters. Several controlled bioreactor types are suitable for the cultivation of hMSCs, including classical fixed bed, fluidized bed and stirred tank reactors, and alternative systems such as wave reactors, wall-rotating systems, and Vertical-Wheel ${ }^{\mathrm{TM}}$ reactors [72]. Moreover, hMSC expansion can also be achieved in spinner flasks. We will not consider spinner flasks, because in our opinion they do not offer the tight environmental control which is needed for 3D cultivation. The most promising bioreactor types for hMSC cultivations are stirred tank reactors (STRs) and fixed-bed reactors (FBRs). These are well characterized and can regulate the cellular microenvironment to ensure the correct proliferation of functional MSCs on microcarriers, in capsules or as agglomerates.

3.1. Stirred Tank Reactors for hMSC Cultivation. The cultivation of hMSCs in STRs usually involves microcarriers, but the growth of hMSCs as aggregates or spheroids has also been described. The maximum scale of hMSC expansion reported thus far was achieved in a $50 \mathrm{~L}$ STR with a $35 \mathrm{~L}$ working volume, resulting in a 50 -fold expansion and $2.6 \cdot 10^{10}$ cells in total [72]. The expansion of hMSCs is usually a batch-mode process, whereas fed-batch processes are often more advantageous because the process starts with a small inoculum in a low working volume, which increases over time with the simultaneous addition of carrier (for carrier-based processes) leading to higher expansion factors [73]. Working with lower inoculum densities for microcarrier-based processes (100 cells $\mathrm{cm}^{-2}, 5$ cells per microcarrier) not only is less expensive but also achieves better hMSC proliferation [74]. In contrast, a low inoculation density does not allow sufficient numbers of intercellular contacts to form when establishing aggregate cultures. An inoculation density of $4.5 \cdot 10^{5}$ cells $\mathrm{mL}^{-1}$ was recommended [75]. It is often advantageous to allow hMSC inoculums to attach to the microcarrier surface or form aggregates with intermittent agitation or none at all. Agitation is a major process parameter because homogenous mixing is necessary to prevent the formation of substrate gradients or cell-loaded microcarrier/aggregates clumping due to cell bridging. The suspension criteria for agitation can be calculated based on the power input, microcarrier type/cell aggregate properties, and cell growth and can be used for process scale-up [76]. The hMSC expansion process occurs in a three-phase system (medium, microcarrier loaded with cells/cell aggregates, and oxygen gas bubbles). Aeration is often low due to the generally low oxygen demand of mammalian cells (oxygen consumption rates: primary hMSCs 90$100 \mathrm{fmol} \mathrm{cell}^{-1} \mathrm{~h}^{-1}$ [77], hMSC cell line (hMSC-TERT) $300 \mathrm{fmol} \mathrm{cell}^{-1} \mathrm{~h}^{-1}$ [78]). Even so, aeration is an important part of mixing, and it is necessary to optimize hMSC expansion in controlled bioreactor systems in order to understand the mixing characteristics [79]. High aeration and especially agitation ensure proper mixing but induce shear stress. In $3 \mathrm{~L}$ microcarrier-based hMSC expansion processes, shear stress is very low (average $0.2 \cdot 10^{-5} \mathrm{~N} \mathrm{~cm}{ }^{-2}$, maximum $1.2 \cdot 10^{-5} \mathrm{~N} \mathrm{~cm}^{-2}$ close to the impeller) and does not affect hMSC growth or stem cell fate [79]. Shear stress has a greater impact in agglomerate cultures because it can prevent the formation of stable aggregates and damage the cells, reducing the number of available cells even further [80].

3.2. Fixed-Bed Reactors for hMSC Cultivation. In FBRs, hMSCs grow on dense macrocarriers or as larger capsules ( $500 \mu \mathrm{m}$ diameter) which form a stable bed inside the reactor. It is challenging to achieve homogeneity and scalability during hMSC expansion in a FBR, although notable improvements have been achieved [81]. The tendency of FBRs to develop channels and gradients in the fixed bed must be addressed during scale-up. However, during hMSC expansion, FBRs are characterized by low constant shear $\left(0.5 \cdot 10^{-5} \mathrm{~N} \mathrm{~cm}^{-2}\right)$ in the whole reactor space, with no shear peaks near the impeller as seen in an STR. Shear forces are a major problem during the scaling up of a STR because more agitation is needed at larger scales, thus creating smaller Kolmogorov eddies [82]. When the eddy size is $\sim 65 \%$ of the microcarrier size, the shear stress can cause significant damage to the cells on the microcarriers. In FBRs, the shear is constant at all scales because superficial velocity stays constant at a value that does not affect hMSC growth (e.g., $1.8 \mathrm{~cm} \mathrm{~min}^{-1}$ ) [83]. Weber et al. [83] described the expansion of hMSC-TERT cells on a nonporous borosilicate glass microcarrier (diameter $2 \mathrm{~mm})$ in a $\operatorname{FBR}\left(300 \mathrm{~cm}^{3}\right)$ according to good manufacturing practice (GMP) requirements. The cells could be expanded to $1.6 \cdot 10^{5}$ cells $\mathrm{cm}^{-2}$ (total $8.7 \cdot 10^{8}$ cells) achieving an expansion factor of 29 . The use of a nonporous microcarrier facilitates the detachment of cells during harvest and prevents mass transfer limitations. However, the harvest efficiency is a major drawback of the FBR. Even after optimization, a maximum $70 \%$ of the expanded cells were harvested with full viability. The viability was reduced by further processing of the harvested hMSCs, for example, during encapsulation, showing that the stress during FBR-harvesting is not acceptable [48]. Similarly, hMSCs have been expanded in a packed-bed reactor at different scales $\left(13-250 \mathrm{~cm}^{3}\right)$, resulting in a harvest efficiency of $84 \%$, but only $71 \%$ of the harvested cells were viable [84]. A maximum 40-fold expansion factor $\left(1.6 \cdot 10^{8}\right.$ cells in total at the $250 \mathrm{~cm}^{3}$ scale) was 
reported, leading to final cell densities of $6 \cdot 10^{4}$ cells cm$^{-2}$ (GFP-MSCs) or $1.5 \cdot 10^{4}$ cells $\mathrm{cm}^{-2}$ (placenta MSCs). A hollow-fiber reactor resulted in an expansion factor of 6 $\left(2.4 \cdot 10^{4}\right.$ cells $\mathrm{cm}^{-2}, 3 \cdot 10^{8}$ cells total) [85], with production rates of $5 \cdot 10^{7}$ cells $^{-1}$ (for further reading, see [86-88]), whereas a $257 \mathrm{~cm}^{3}$ fibrous-bed reactor achieved a 9-fold expansion factor $\left(3 \cdot 10^{3}\right.$ cells cm$^{-2}, 9.2 \cdot 10^{7}$ cells total) [89]. Therefore, although hMSCs can be expanded in FBRs, the harvest problem remains to be addressed.

The cultivation of hMSCs in an FBR can also be used for hMSC differentiation or regeneration. Here, nongrowing hMSCs are cultivated in the form of capsules or aggregates to improve cell viability or functionality. This can be set as a second process following the expansion step to regenerate cells, which suffer during the harvest and encapsulation procedures. For example, 2000-3000 nonproliferating hMSCTERT cells were encapsulated in an alginate double layer, generating capsules with a core diameter of $\sim 400 \mu \mathrm{m}$ and an overall diameter of 500-600 $\mu \mathrm{m}$. The capsules were cultivated as a fixed bed in a single-use syringe in a perfusion arrangement. The vitality and also the quality of the cells increased over the duration of cultivation, whereas the cell number declined. This may reflect the degradation of necrotic cells, which suffered during the harvest, encapsulation, or freezing procedures. For some differentiation setups, for example, osteogenic differentiation of hMSCs, scaffolds mimicking the in vivo structures can be 3D-printed and used in a fixed-bed reactor. This gives an additional differentiation stimulus to the cells as they respond to surface stiffness and structure $[90,91]$.

\section{Bioreactor Technologies for 3D Beta Cell Approaches}

Compared to hMSCs, where bioreactor cultivation has become very common, beta cells are rarely cultivated in bioreactors. Currently, the mass production of beta cell in vitro is challenging and has not succeeded in the way researchers hoped. In standard 2D cultures, beta cells lose their functionalities, including the ability to secrete insulin in a glucose-dependent manner. This can be addressed by $3 \mathrm{D}$ cultures because the 3D cell-cell contacts preserve the beta cell phenotype, improve the regulation of insulin gene expression [92, 93], achieve higher cell viability, and increase insulin secretion after glucose stimulation [92, 94-96]. But even in 3D cultures, beta cells tend to grow extremely slow. Growth rates $(\mu)$ for porcine islets varied from 0.17 to $0.27 \mathrm{~d}^{-1}$, which is a population-doubling time $\left(t_{\mathrm{D}}\right)$ of up to $100 \mathrm{~h}$ [97]. Engineered beta cell lines may be suitable because they often grow much more quickly than wild-type cells (e.g., $1.1 \mathrm{~B} 4$ cells: $\mu 0.84 \mathrm{~d}^{-1}, t_{\mathrm{D}} 20 \mathrm{~h}$ ), but this is only possible if the engineered cells show the desired properties. Beta cells also consume a lot of oxygen, but if we compare the oxygen consumption rates of beta cells (primary cell: $23 \mathrm{fmol} \mathrm{cell}^{-1}$ $\mathrm{h}^{-1}$, max. $q_{\text {ox }} 139 \mathrm{fmol} \mathrm{cell}^{-1} \mathrm{~h}^{-1}$ [98]; bTC3: $114 \mathrm{fmol} \mathrm{cell}^{-1}$ $\mathrm{h}^{-1}$, MIA PaCa-2: $108 \mathrm{fmolcell}^{-1} \mathrm{~h}^{-1}$ [99]) or islets $\left(230 \mathrm{fmol} \mathrm{cell}^{-1} \mathrm{~h}^{-1}\right.$ [100]) with other cells ( $q_{\mathrm{ox}}$ from 3.6 to $1260 \mathrm{fmol} \mathrm{cell}^{-1} \mathrm{~h}^{-1}$ [99], e.g., hepatocytes $324 \mathrm{fmol} \mathrm{cell}^{-1}$ $\mathrm{h}^{-1}$, adipocytes $430 \mathrm{fmolcell}^{-1} \mathrm{~h}^{-1}$ ), the rates are not excessive. It is clear that beta cells suffer from hypoxia and die if their oxygen demands are not met, but other obligate aerobic cells behave in the same manner, so this is not an exclusive property of beta cells. It is interesting that the oxygen demand of beta cells is coupled to their insulin secretion and can be increased by adding glucose to the medium. Under basal conditions (5.8 mM glucose) the $q_{\text {ox }}$ of human islets was $1.5 \cdot 10^{4} \mathrm{fmol} \mathrm{IE}^{-1} \mathrm{~h}^{-1}$, which is less than half the value in the presence of $33 \mathrm{mM}$ glucose $\left(q_{\mathrm{ox}}=3.6 \cdot 10^{4} \mathrm{fmo}-\right.$ $\left.1 \mathrm{IE}^{-1} \mathrm{~h}^{-1}\right)$. Insulin secretion increased in proportion with the glucose concentration in this setup [101]. To summarize, the cellular microenvironment and nutrient supply for beta cells must be tightly controlled, maybe even tighter than those for hMSCs. This can only be achieved in controlled bioreactor systems. However, cell expansion in bioreactors is uncommon for beta cells. The few bioreactor concepts that have been developed are mainly for tissue engineering or diabetes models. These systems are often very small, that is, down to microreactor scales of a few milliliters. Microreactors in a microtiter well format can be suitable for drug screening [102], but larger bioreactor concepts are needed for the high-cell-mass expansion and cultivation of beta cells as discussed below.

4.1. Rotating Wall Vessel Reactor for Beta Cell Cultivation. The rotating wall vessel reactor (RWVR) has been used for the cultivation of human and other mammalian islets in aggregate culture. The rotating wall applies low shear stress, but there is proper mixing which ensures efficient nutrient and oxygen transfer within the medium. The islets are suspended by microgravity, which is achieved by the continuous rotation of the medium. A drawback of this reactor type is the clumping of the islets, which has been addressed by scaffold culture [103]. The functionality of bioreactor-cultivated murine islets improves as shown by the higher SI value compared to freshly isolated islets. The bioreactor-cultivated islets also developed unique and multiple nutritional channels [104]. Human islets (50-150 IE mL ${ }^{-1}$ ) cultivated in a RWVR $\left(10 \mathrm{~mL}, 30^{\circ} \mathrm{C}\right)$ showed a stable islet structure and higher SI values compared to $2 \mathrm{D}$ static cultures. Dispersed islet cells reaggregated within the reactor [105]. A murine pancreatic cell line (b-TC-6) cultivated on the microcarrier Cytodex-3 in the RWVR proliferated over 12 days with improved insulin gene expression and a clear response to glucose-stimulation [106]. The murine pancreatic cell line MIN6 was used to form spheroids in a RWVR. The optimal seeding density was $6 \cdot 10^{6}$ cells $\mathrm{mL}^{-1}$, because with increasing seeding densities $\left(2 \cdot 10^{5}\right.$ to $6 \cdot 10^{6}$ cell $\mathrm{mL}^{-1}$ ) the number of spheroids increased (14 to 1100 ) but the average spheroid diameter (600 to $220 \mu \mathrm{m}$ ) and cells per spheroid $\left(184 \cdot 10^{3}\right.$ to $\left.9 \cdot 10^{3}\right)$ decreased. The spheroids formed in the RWVR showed higher SI values than 2D-cultured MIN6 cells, the shape and size of spheroid cells was similar to pancreatic islets, and the expression of the genes insulin2, glucokinase, SETD1A, and Kir6.2 was stronger than in MIN6 cells from 2D cultures [92]. Therefore, the RWVR helps to improve the functionality of islets and beta cell aggregates in vitro and could also be used for beta cell expansion. However, most published data reflect small-scale experiments which would not satisfy the needs of cell therapy. 
4.2. Stirred-Tank and Fixed-Bed Reactors for Beta Cell Cultivation. Like hMSCs, beta cells can be cultivated in classical bioreactor systems which have well-characterized scale-up parameters. In contrast to hMSCs, beta cells are cultivated in aggregates or capsules rather than on microcarriers. Beta cell expansion using microcarriers in an STR was carried out using trypsin-dispersed human pancreatic islet cells grown on $1 \mathrm{~g} \mathrm{~L}^{-1}$ Cytodex-3 microcarrier. With a $1.2 \mathrm{~L}$ working volume, the cell number was doubled, reaching $3.1 \cdot 10^{5}$ cells cm $^{-2}$ (total $1 \cdot 10^{8}$ cells). Cell growth was very slow $\left(\mu=0.11 \mathrm{~d}^{-1}\right)$, but the cells were functional in that they secreted insulin at a rate of $4.5 \cdot 10^{3} \mathrm{fg} \mathrm{cell}^{-1}$ [52]. The pancreatic cell line BRIN-BD11 was expanded in a STR with a $1 \mathrm{~L}$ working volume on Hillex or PlasticPlus microcarriers (both SoloHill), achieving an expansion factor of 2.8. Compared to 2D cultures, cells grow faster in bioreactors $\left(\mu=0.49-0.52 \mathrm{~d}^{-1} ; t_{\mathrm{D}} 31\right.$ to $\left.34 \mathrm{~h}\right)$. Cells expanded on PlasticPlus microcarriers produced 2.6-fold more insulin than Hillex and 2D cultures. This provides another excellent example of how the growth surface material and its properties might influence the behavior of beta cells [107]. We found no data for beta cell aggregate/islet cultivation in an STR although several publications discussed beta cell cultivation in spinner flasks but described this as stirred bioreactor cultivation. As stated above, we do not agree with this classification because spinner flasks lack any form of environmental control and are unsuitable for large-scale expansion. Even so, because of the missing data for beta cell aggregates in STRs, we will review helpful results from spinner cultivations. Porcine pancreatic cells were seeded in spinner flasks in different densities $\left(6.3 \cdot 10^{3}, 5 \cdot 10^{4}\right.$, and $1.3 \cdot 10^{5}$ cells $\mathrm{mL}^{-1}$ ). The high-density culture achieved a ninefold increase in the number of insulin-releasing cells, and many glucose-responsive spheroids were formed after 9 days [108]. MIN6 cells formed aggregates in spinner flasks with their diameter increasing from 100 to $800 \mu \mathrm{m}$ over time. With an aggregate size $>200 \mu \mathrm{m}$, cell viability decreased probably due to mass transport limitations. An expansion factor of 14 was achieved with slightly longer growth rates $\left(t_{\mathrm{D}} 87 \mathrm{~h}\right) \mathrm{com}$ pared to $2 \mathrm{D}$ culture $\left(t_{\mathrm{D}} 72 \mathrm{~h}\right)$. The pseudoislets formed in spinner flasks had lots of the structures of native islets, whereas glucose-dependent insulin release was not significantly improved compared to 2D cultures [109].

Fixed-bed systems have also been used to cultivate beta cells. Porcine pancreatic cells were grown in an alginatefilled hollow fiber FBR where the single cells formed aggregates. The cells remained viable and secreted more insulin compared to an aggregate suspension culture [110]. Hollow fiber FBR has been used to expand rat insulinoma cells fourfold, reaching a final density of $5.7 \cdot 10^{4}$ cell cm$^{-2}\left(1.3 \cdot 10^{8}\right.$ cells in total) [111]. Nothing has been reported about the harvest of beta cells from FBRs, but it can be assumed that the same problems that apply to hMSCs were encountered. STRs or FBR using microcarriers or aggregates seemed to be suitable for beta cell expansion and cultivation, although more basic work is needed to understand these cell changes even in classical bioreactors.

4.3. Other Reactor Types Used for Beta Cells. An interesting alternative to the systems presented above is the fluidized- bed reactor. In a brand new study, alginate-encapsulated MIN6 cells were cultivated in a small fluidized-bed reactor $\left(15 \mathrm{~cm}^{3}\right)$. The fluidization point was determined, and full fluidization occurred at a superficial velocity of $1.13 \mathrm{~cm} \mathrm{~min}^{-1}$. The cells within the capsules (diameter $180-220 \mu \mathrm{m}$ ) were viable over 7 days and showed a higher SI value (3.7) in the fluidized-bed reactor compared to static cultivation $(S I=2.3)$ [112]. Certain other bioreactor types may be suitable for beta cell cultivation, including wave reactor systems, but none of these has yet been described for this purpose.

In summary, few studies have considered beta cell/islet cultivation in bioreactors. One can argue that beta cell expansion can be solved by the expansion and subsequent pancreatic differentiation of pluripotent iPSCs. However, this does not address the issue of maintaining these cells in a functional state in vitro. The persistence of beta cell function in vitro requires an environment that is sufficiently similar to the in vivo context. Islets per se satisfy of these requirements such as the provision of an ECM and supporting cell types such as endothelial and mesenchymal cells carried over from islet isolation, whereas iPSCs do not. In the human body, islets are surrounded by a milieu of ECM and mesenchymal, endothelial, neuronal, and exocrine cells, many of which act to support beta cell identity and functionality [113]. Current culture conditions must be modified to maintain functional beta cells, and within bioreactors, optimal 3D environments can be created. Furthermore, rather than cultivating beta cells in isolation, cocultivation with other cell types, for example, supporting hMSCs, might bring more success.

\section{Engineering of Bioreactor Cocultivation with MSCs and Beta Cells}

Cocultivation at larger scales is needed to produce an appropriate number of functional beta cells for cell therapy or for large-scale drug screening. Large-scale cocultures in bioreactors have only rarely been reported for mammalian cells. At such large scales, the problem of heterogeneity arises, which can lead to instability within the bioreactor and a loss of cell viability, so a well-balanced and tightly controlled culture environment is needed at larger scales to stabilize the complexity of the coculture. Before cocultivation is possible in a chosen bioreactor system, preliminary investigations are needed to define the coculture mode (direct, indirect, or mixed). This can be achieved at smaller scales, for example, in transwell plates or microreactors. Because secreted factors are important for hMSC and beta cell cocultivation, the hydrodynamics in bioreactors, which influence the distribution of the secreted molecules, should be considered at an early stage [114]. Furthermore, the cocultivation ratios of the cells need to be determined. Depending on the process setup and the growth rates of the cells, the population sizes in a coculture often differ vastly, with one being much more dominant. For hMSCs and beta cells, hMSC outcompete beta cells because their growth rate is up to three times faster (worst case scenario: $\mu$ (hMSC) $=0.5 \mathrm{~d}^{-1}, \mu$ (beta cells $)=0.17 \mathrm{~d}^{-1}$ ). To reach a stable population, or even better a coculture with dominant beta cells, the ratios and 
culture conditions have to be optimized. However, the growth rates of cocultivated hMSCs and beta cells may differ from the pure culture growth rates because the cells might influence each other's proliferation, as shown for hMSCs cocultured with human umbilical vein endothelial cells (HUVECs) [115]. The ratio can also influence the therapeutic effect of the cells and their behavior in vivo.

\subsection{Important Parameters for hMSCs and Beta Cells. Cocul-} tured hMSCs and beta cells are biologically very different, but from a bioprocessing perspective, they have similar characteristics. Biologically, hMSCs are mesoderm-derived multipotent cells with a high differentiation capacity, whereas beta cells are fully differentiated, unipotent cells derived from the endoderm. From the bioprocessing perspective, both cell types grow as adherent cells within the same temperature range $\left(30-37^{\circ} \mathrm{C}\right)$ and $\mathrm{pH}$ range $(7.0-7.4)$, and they consume the same nutrients (key metabolite $=$ glucose) and oxygen at similar rates (Table 1). Because islets consist mainly of beta cells (a single islet contains 1560 cells, of which 1140 are beta cells [116]), the properties of beta cells are primarily responsible for islet behavior in bioreactors. The growth rates of hMSCs and beta cells can differ significantly as stated above, so it can be useful to establish an optimal environment for beta cells in the cocultivation setup, thus slowing the growth of hMSCs to a desired level. However, the hMSCs must still secrete all the trophic factors needed to support the beta cells. The behavior of both cell types in coculture is difficult to predict because they influence each other in unknown ways. Saleh et al. [117] show the positive effect of cocultures of hMSCs and HUVECs compared to cocultures of hMSCs and adult human dermal fibroblasts (HDF). The HUVEC/ MSC cocultures formed hybrid spheroids comprising elongated and flattened endothelial-like cells on the outer layer whereas such cells did not form in the HDF/MSC spheroids. A clear boundary between cell morphologies indicates the self-arrangement of the cell populations, which was confirmed by transmission electron microscopy. The HUVEC/ MSC spheroids showed enhanced osteogenic differentiation compared to the HDF/MSC spheroids, and the reverse effect was shown for adipogenic differentiation. This study therefore suggested that somatic cells promote the self-assembly, differentiation, and activity of hMSCs. All these parameters must be considered and balanced in a cocultivation setup.

\subsection{Suitable Cocultivation Concepts for hMSCs and Beta Cells} in Bioreactor Systems. New bioreactor systems are not necessary for the cocultivation of hMSCs and beta cells because the classical systems appear to be suitable. However, it might be useful to separate cell expansion from cocultivation; that is, first expand the pure cultures to generate the cells needed for the coculture and then combine them to improve the function of beta cells in a second process step. For the expansion process, it can be sufficient to improve the growth of beta cells using conditioned medium from hMSCs. Carrierbased expansion in a STR or FBR is suitable for the expansion process, because new resolvable carriers will soon be available commercially to address the harvest problem in these processes. Here, the cells are not trypsinized, but the carrier material is degraded to harvest the cells, thus preserving the surface proteins of the cells to improve their functionality and reduce the stress during harvest. After expansion, the functionality of the beta cells can be improved by cocultivation. Alternatively, the expansion and functionalization of beta cells can also be combined in one process step. Process engineering is a challenging part of the development of a cocultivation strategy. Various aspects need to be considered; for example, processes must fulfill the demands of GMP and process analytical technology (PAT) and the culture medium must satisfy the needs of both cell lines. It is a matter of balancing the demands of two cell types in a system with many unknown variables. In our opinion, hMSCs are more robust in vitro than beta cells, so the latter should be favored when setting the process parameters. Certain cocultivation bioreactor concepts may be suitable depending on the cocultivation mode (Figure 2). For direct cocultivation, STRs, FBRs, and fluidized-bed reactors may be appropriate, in batch or even better in fed-batch or perfusion mode. The beta cells and hMSCs can be cultivated as mixed aggregates, capsules, or on carriers. Indirect cocultivation offers more options, including elegant approaches such as using the encapsulated beta cell aggregates as carriers for the hMSCs. In the indirect cocultivation approach, it is also possible to create a cellspecific optimal microenvironment for each cell type, for example, by compartmentalizing them with membranes. Future work will focus on realizing these cocultivation bioreactor concepts for hMSCs and beta cells and testing which concepts achieve the best results.

\section{Outlook and Conclusions}

In most cases, hMSCs are used alone for cell therapy, but more recently, hMSCs have been considered as in vivo supporter cells for other cell types, including beta cells. One major problem with these treatments is that a large proportion of the hMSCs die at the transplantation site. The hMSCs are not able to achieve their full potential, which reduces the therapeutic efficacy. Beta cells also die at the transplantation site, but a combination of hMSCs and beta cells has been shown to support greater survival. Furthermore, the hMSCs can strengthen the beta cells and improve their functionality in vitro when the cells are cocultivated. Here, it remains unclear which cocultivation mode is the best and which hMSC type is most suitable. Because hMSCs can be isolated from different sources, for example, bone marrow, adipose tissue, and umbilical cord, their properties are distinct. Umbilical cord hMSCs are very young and primitive and therefore offer advantages in a direct cocultivation mode. They can differentiate into islet-like clusters and thereby promote beta cell functionality. Although the hMSC types share many secreted factors in common, their secretome differs in terms of the concentration of these factors as well as other factors which are only secreted by certain hMSC types [118]. Based on the type-specific secretome, specific hMSC types are likely to improve the functionality of different cells in indirect cocultivation approaches. The hMSC type which is best to restore the functionality of beta cells is unknown. It is difficult to generate large numbers of medical grade 
TABLE 1: Process-relevant parameters for human mesenchymal stem/stromal cells (hMSCs) and islets or beta cells based on our own data and the literature.

\begin{tabular}{|c|c|c|c|c|c|c|}
\hline & & hMSC & hMSC-TERT & Islet & $1.1 \mathrm{~B} 4$ & $\mathrm{MIN6}^{*}$ \\
\hline \multirow{4}{*}{$\begin{array}{l}\text { Biological } \\
\text { parameter }\end{array}$} & $\mu\left[\mathrm{d}^{-1}\right]$ & $0.33-1.1$ & $0.4-0.7^{\#}$ & $0.11[49]$ & 0.84 & $0.19-0.23[100]$ \\
\hline & $t_{\mathrm{D}}[\mathrm{h}]$ & $15-50$ & $24-42$ & 151 & 20 & $72-88$ \\
\hline & $q_{\mathrm{GLC}}\left[\mathrm{pmol}\right.$ cell $\left.{ }^{-1} \mathrm{~h}^{-1}\right]$ & $0.13-0.7$ & $0.02-0.5^{\#}$ & n.d. & $0.08^{\#}$ & n.d. \\
\hline & $q_{\mathrm{ox}}\left[\mathrm{fmol} \mathrm{cell}{ }^{-1} \mathrm{~h}^{-1}\right]$ & $90-100[77]$ & $300[74]$ & $23-139$ [89] & \multicolumn{2}{|c|}{ n.d. } \\
\hline \multirow{11}{*}{$\begin{array}{l}\text { Process } \\
\text { parameter }\end{array}$} & Seeding density [cells $\mathrm{cm}^{-2}$ ] & \multicolumn{2}{|c|}{$1000-10,000^{\#}$} & \multirow{3}{*}{$\begin{array}{l}\text { Depends on } \\
\text { reaggregation method }\end{array}$} & $5000-10,000^{\#}$ & \multirow{3}{*}{$\begin{array}{c}>80,000 \\
2-3 \cdot 10^{5}(\text { static })^{\#}\end{array}$} \\
\hline & Final cell density [cells $\mathrm{cm}^{-2}$ ] & \multicolumn{2}{|c|}{ 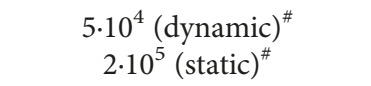 } & & $1 \cdot 10^{5}(\text { static })^{\#}$ & \\
\hline & Max. working volume $[\mathrm{L}]$ & 35 & $2.4^{\#}$ & & $<0.1$ & \\
\hline & $\mathrm{pH}[-]$ & \multicolumn{5}{|c|}{$7.0-7.4$} \\
\hline & $T\left[{ }^{\circ} \mathrm{C}\right]$ & \multicolumn{5}{|c|}{$30-37$} \\
\hline & $k_{\mathrm{L}} \mathrm{a}\left[\mathrm{h}^{-1}\right]^{+}$ & 0.6 & 4.4 & 0.2 & & n.d. \\
\hline & Shear sensitivity $\tau\left[\mathrm{N} \mathrm{cm}^{-2}\right]$ & \multicolumn{2}{|c|}{$1.2 \cdot 10^{-5}$} & \multicolumn{3}{|c|}{ Mostly static cultivation with low shear } \\
\hline & Growth surface material & \multicolumn{2}{|c|}{$\begin{array}{l}\text { TC-treated polystyrene, } \\
\text { micro- and macrocarrier } \\
\text { with different coatings }\end{array}$} & \multicolumn{3}{|c|}{ Mainly TC-treated culture vessels (polystyrene) } \\
\hline & Aggregate formation & \multicolumn{2}{|c|}{ Possible, but lower tendency } & \multicolumn{3}{|c|}{ Strong tendency } \\
\hline & Culture media & \multicolumn{2}{|c|}{ SCM, SFM, CDM } & \multicolumn{3}{|c|}{ SCM with $10-20 \%$ serum } \\
\hline & Glucose concentration [mM] & \multicolumn{2}{|c|}{ Usually $5.5,5-25$} & \multicolumn{3}{|c|}{5.8 recommend, $5-25$} \\
\hline
\end{tabular}

Abbreviations: $\mu$ : growth rate; $t_{\mathrm{D}}$ : doubling time; $q_{\mathrm{GLC}}$ : glucose consumption; $q_{\mathrm{ox}}:$ oxygen consumption; $k_{\mathrm{L}}$ a: oxygen transfer coefficient; TC: tissue culture; SCM: serum-containing medium; SFM: serum-free medium; CDM: chemically defined medium; n.d.: not determined. ${ }^{*}$ Murine origin; ${ }^{*}$ own data; ${ }^{+}$aeration with air.

hMSCs and functional beta cells for therapy, and still little is known about the behavior of cells in 3D structures; thus, new $3 \mathrm{D}$ cocultivation concepts are required. Few researchers have focused on cocultivation concepts for mammalian cells in liter-scale bioreactors, and no such cultivation strategies have been reported for hMSCs and beta cells or other somatic cells. These production scales are necessary for cell therapy and even for large-scale drug screening. Therefore, it is time to concentrate on the open bioengineering questions for hMSCs in coculture with beta cells and other somatic cells in bioreactors. Otherwise, the groundbreaking efforts made in basic research cannot be brought into clinical practice without a significant delay. The 422 million diabetes patients are waiting for an option that cures their disease, but without bioengineering and suitable 3D bioreactor concepts, beta cell therapy cannot succeed.

\section{Conflicts of Interest}

The authors declare that there is no conflict of interest regarding the publication of this article.

\section{Acknowledgments}

The authors would like to thank Dr. Richard M. Twyman for language editing.

\section{References}

[1] WHO, Global Report On Diabetes, WHO Press, Geneva, Switzerland, 2017.
[2] P. Tsasis, J. Wu, A. An et al., "Conceptualizing type 2 diabetes and its management," Journal of Multidisciplinary Healthcare, vol. 9, pp. 133-136, 2016.

[3] W. Siegenthaler and B. R. Amann-Vesti, "Klinische Pathophysiologie," Thieme, 2006.

[4] P. A. Lysy, E. Corritore, and E. M. Sokal, "New insights into diabetes cell therapy," Current Diabetes Reports, vol. 16, no. 5 , p. 38, 2016.

[5] J. R. Benthuysen, A. C. Carrano, and M. Sander, "Advances in $\beta$ cell replacement and regeneration strategies for treating diabetes," The Journal of Clinical Investigation, vol. 126, no. 10, pp. 3651-3660, 2016.

[6] L. Zang, H. Hao, J. Liu, Y. Li, W. Han, and Y. Mu, "Mesenchymal stem cell therapy in type 2 diabetes mellitus," Diabetology \& Metabolic Syndrome, vol. 9, no. 1, p. 36, 2017.

[7] M. L. Weiss and D. L. Troyer, "Stem cells in the umbilical cord," Stem Cell Reviews, vol. 2, no. 2, pp. 155-162, 2006.

[8] J. P. McGuirk, J. R. Smith, C. L. Divine, M. Zuniga, and M. L. Weiss, "Wharton's jelly-derived mesenchymal stromal cells as a promising cellular therapeutic strategy for the management of graft-versus-host disease," Pharmaceuticals, vol. 8, no. 2, pp. 196-220, 2015.

[9] T. Deuse, M. Stubbendorff, K. Tang-Quan et al., "Immunogenicity and immunomodulatory properties of umbilical cord lining mesenchymal stem cells," Cell Transplantation, vol. 20, no. 5, pp. 655-667, 2011.

[10] K. H. Yoo, I. K. Jang, M. W. Lee et al., "Comparison of immunomodulatory properties of mesenchymal stem cells derived from adult human tissues," Cellular Immunology, vol. 259, no. 2, pp. 150-156, 2009.

[11] S. J. Prasanna, D. Gopalakrishnan, S. R. Shankar, and A. B. Vasandan, "Pro-inflammatory cytokines, IFN $\gamma$ and TNF $\alpha$, influence immune properties of human bone marrow and 
Wharton jelly mesenchymal stem cells differentially," PLoS One, vol. 5, no. 2, article e9016, 2010.

[12] M. L. Weiss, C. Anderson, S. Medicetty et al., "Immune properties of human umbilical cord Wharton's jelly-derived cells," Stem Cells, vol. 26, no. 11, pp. 2865-2874, 2008.

[13] T. J. Bartosh, J. H. Ylöstalo, A. Mohammadipoor et al., "Aggregation of human mesenchymal stromal cells (MSCs) into 3D spheroids enhances their antiinflammatory properties," Proceedings of the National Academy of Sciences of the United States of America, vol. 107, no. 31, pp. 13724-13729, 2010.

[14] G. Ren, X. Zhao, L. Zhang et al., "Inflammatory cytokineinduced intercellular adhesion molecule- 1 and vascular cell adhesion molecule- 1 in mesenchymal stem cells are critical for immunosuppression," The Journal of Immunology, vol. 184, pp. 2321-2328, 2010.

[15] A. I. Caplan and J. E. Dennis, "Mesenchymal stem cells as trophic mediators," Journal of Cellular Biochemistry, vol. 98, no. 5, pp. 1076-1084, 2006.

[16] W. G. Gunn, A. Conley, L. Deininger, S. D. Olson, D. J. Prockop, and C. A. Gregory, "A crosstalk between myeloma cells and marrow stromal cells stimulates production of DKK1 and interleukin-6: a potential role in the development of lytic bone disease and tumor progression in multiple myeloma," Stem Cells, vol. 24, no. 4, pp. 986-991, 2006.

[17] H. Ohtaki, J. H. Ylostalo, J. E. Foraker et al., "Stem/progenitor cells from bone marrow decrease neuronal death in global ischemia by modulation of inflammatory/immune responses," Proceedings of the National Academy of Sciences of the United States of America, vol. 105, no. 38, pp. 1463814643, 2008.

[18] R. H. Lee, A. A. Pulin, M. J. Seo et al., "Intravenous hMSCs improve myocardial infarction in mice because cells embolized in lung are activated to secrete the anti-inflammatory protein TSG-6," Cell Stem Cell, vol. 5, no. 1, pp. 54-63, 2009.

[19] C. L. Elseberg, J. Leber, D. Salzig et al., "Microcarrier-based expansion process for hMSCs with high vitality and undifferentiated characteristics," The International Journal of Artificial Organs, vol. 35, no. 2, pp. 93-161, 2012.

[20] B. Keymeulen, P. Gillard, C. Mathieu et al., "Correlation between $\beta$ cell mass and glycemic control in type 1 diabetic recipients of islet cell graft," Proceedings of the National Academy of Sciences of the United States of America, vol. 103, no. 46, pp. 17444-17449, 2006.

[21] J. W. Haycock, "3D cell culture: a review of current approaches and techniques," Methods in Molecular Biology, vol. 695, pp. 1-15, 2011.

[22] J. Lee, M. J. Cuddihy, and N. A. Kotov, "Three-dimensional cell culture matrices: state of the art," Tissue Engineering Part B: Reviews, vol. 14, no. 1, pp. 61-86, 2008.

[23] L. G. Griffith and M. A. Swartz, "Capturing complex 3D tissue physiology in vitro," Nature Reviews. Molecular Cell Biology, vol. 7, no. 3, pp. 211-224, 2006.

[24] X. Yin, B. E. Mead, H. Safaee, R. Langer, J. M. Karp, and O. Levy, "Engineering stem cell organoids," Cell Stem Cell, vol. 18, no. 1, pp. 25-38, 2016.

[25] A. B. Bernard, C.-C. Lin, and K. S. Anseth, "A microwell cell culture platform for the aggregation of pancreatic $\beta$-cells," Tissue Engineering Part C: Methods, vol. 18, no. 8, pp. 583$592,2012$.
[26] B. R. Lee, J. W. Hwang, Y. Y. Choi et al., "In situ formation and collagen-alginate composite encapsulation of pancreatic islet spheroids," Biomaterials, vol. 33, no. 3, pp. 837-845, 2012.

[27] J. Amin, K. Ramachandran, S. J. Williams, A. Lee, L. Novikova, and L. Stehno-Bittel, "A simple, reliable method for high-throughput screening for diabetes drugs using $3 \mathrm{D} \beta$ cell spheroids," Journal of Pharmacological and Toxicological Methods, vol. 82, pp. 83-89, 2016.

[28] E. S. O'Sullivan, A. S. Johnson, A. Omer, J. Hollister-Lock et al., "Rat islet cell aggregates are superior to islets for transplantation in microcapsules," Diabetologia, vol. 53, no. 5, pp. 937-945, 2010.

[29] M. W. Laschke and M. D. Menger, "Life is 3D: boosting spheroid function for tissue engineering," Trends in Biotechnology, vol. 35, no. 2, pp. 133-144, 2017.

[30] M. F. Pittenger, A. M. Mackay, S. C. Beck et al., "Multilineage potential of adult human mesenchymal stem cells," Science, vol. 284, no. 5411, pp. 143-147, 1999.

[31] K. Mcintosh, S. Zvonic, S. Garrett et al., "The immunogenicity of human adipose-derived cells: temporal changes in vitro," Stem Cells, vol. 24, no. 5, pp. 1246-1253, 2006.

[32] S. Sart, A.-C. Tsai, Y. Li, and T. Ma, "Three-dimensional aggregates of mesenchymal stem cells: cellular mechanisms, biological properties, and applications," Tissue Engineering Part B: Reviews, vol. 20, no. 5, pp. 365-380, 2014.

[33] T. Ma, A.-C. Tsai, and Y. Liu, "Biomanufacturing of human mesenchymal stem cells in cell therapy: influence of microenvironment on scalable expansion in bioreactors," Biochemical Engineering Journal, vol. 108, pp. 44-50, 2016.

[34] J. H. Ylostalo, T. J. Bartosh, A. Tiblow, and D. J. Prockop, "Unique characteristics of human mesenchymal stromal/progenitor cells pre-activated in 3-dimensional cultures under different conditions," Cytotherapy, vol. 16, no. 11, pp. 14861500, 2014.

[35] T. J. Bartosh, J. H. Ylöstalo, N. Bazhanov, J. Kuhlman, and D. J. Prockop, "Dynamic compaction of human mesenchymal stem/precursor cells into spheres self-activates caspasedependent IL1 signaling to enhance secretion of modulators of inflammation and immunity (PGE2, TSG6, and STC1)," Stem Cells, vol. 31, pp. 2443-2456, 2013.

[36] J. H. Ylöstalo, T. J. Bartosh, K. Coble, and D. J. Prockop, "Human mesenchymal stem/stromal cells cultured as spheroids are self-activated to produce prostaglandin E2 that directs stimulated macrophages into an anti-inflammatory phenotype," Stem Cells, vol. 30, no. 10, pp. 2283-2296, 2012.

[37] P. R. Baraniak and T. C. McDevitt, "Scaffold-free culture of mesenchymal stem cell spheroids in suspension preserves multilineage potential," Cell and Tissue Research, vol. 347, no. 3, pp. 701-711, 2012.

[38] R.-Z. Lin, R.-Z. Lin, and H.-Y. Chang, "Recent advances in three-dimensional multicellular spheroid culture for biomedical research," Biotechnology Journal, vol. 3, no. 9-10, pp. 1172-1184, 2008.

[39] P. Wuchter, J. Boda-Heggemann, B. K. Straub et al., "Processus and recessus adhaerentes: giant adherens cell junction systems connect and attract human mesenchymal stem cells," Cell and Tissue Research, vol. 328, no. 3, pp. 499-514, 2007.

[40] E. J. Lee, S. J. Park, S. K. Kang et al., "Spherical bullet formation via E-cadherin promotes therapeutic potency of mesenchymal stem cells derived from human umbilical cord blood 
for myocardial infarction," Molecular Therapy, vol. 20, pp. 1424-1433, 2012.

[41] R. Peng, X. Yao, B. Cao, J. Tang, and J. Ding, "The effect of culture conditions on the adipogenic and osteogenic inductions of mesenchymal stem cells on micropatterned surfaces," Biomaterials, vol. 33, no. 26, pp. 6008-6019, 2012.

[42] P. R. Baraniak, M. T. Cooke, R. Saeed, M. A. Kinney, K. M. Fridley, and T. C. McDevitt, "Stiffening of human mesenchymal stem cell spheroid microenvironments induced by incorporation of gelatin microparticles," Journal of the Mechanical Behavior of Biomedical Materials, vol. 11, pp. 6371, 2012.

[43] M. S. STEINBERG, "On the mechanism of tissue reconstruction by dissociated cells, I. Population kinetics, differential adhesiveness, and the absence of directed migration," Proceedings of the National Academy of Sciences of the United States of America, vol. 48, no. 9, pp. 1577-1582, 1962.

[44] B. M. de Souza, A. P. Bouças, F. D. Oliveira et al., "Effect of co-culture of mesenchymal stem/stromal cells with pancreatic islets on viability and function outcomes: a systematic review and meta-analysis," Islets, vol. 9, no. 2, pp. 30-42, 2017.

[45] A. Scuteri, E. Donzelli, V. Rodriguez-Menendez et al., "A double mechanism for the mesenchymal stem cells' positive effect on pancreatic islets," PLoS One, vol. 9, no. 1, article e84309, 2014.

[46] Y. Jun, A. R. Kang, J. S. Lee et al., "Microchip-based engineering of super-pancreatic islets supported by adipose-derived stem cells," Biomaterials, vol. 35, no. 17, pp. 4815-4826, 2014.

[47] B. C. Heng, J. Li, A. K.-L. Chen et al., "Translating human embryonic stem cells from 2-dimensional to 3-dimensional cultures in a defined medium on laminin- and vitronectincoated surfaces," Stem Cells and Development, vol. 21, no. 10, pp. 1701-1715, 2012.

[48] D. Salzig, A. Schmiermund, P. P. Grace, C. Elseberg, C. Weber, and P. Czermak, "Enzymatic detachment of therapeutic mesenchymal stromal cells grown on glass carriers in a bioreactor," The Open Biomedical Engineering Journal, vol. 7, no. 1, pp. 147-158, 2013.

[49] Q. A. Rafiq, K. Coopman, A. W. Nienow, and C. J. Hewitt, "Systematic microcarrier screening and agitated culture conditions improves human mesenchymal stem cell yield in bioreactors," Biotechnology Journal, vol. 11, no. 4, pp. 473-486, 2016.

[50] J. Leber, J. Barekzai, M. Blumenstock, B. Pospisil, D. Salzig, and P. Czermak, "Microcarrier choice and bead-to-bead transfer for human mesenchymal stem cells in serumcontaining and chemically defined media," Process Biochemistry, vol. 59, pp. 255-265, 2017.

[51] A. J. Bone and I. Swenne, "Microcarriers: a new approach to pancreatic islet cell culture," In Vitro, vol. 18, no. 2, pp. 141-148, 1982.

[52] C. Mantovani Mda, M. M. da Conceição, A. J. Ferreira et al., "Immobilization of primary cultures of insulin-releasing human pancreatic cells," Islets, vol. 1, no. 3, pp. 224-231, 2009.

[53] S. Del Guerra, C. Bracci, K. Nilsson et al., "Entrapment of dispersed pancreatic islet cells in CultiSpher-S macroporous gelatin microcarriers: preparation, in vitro characterization, and microencapsulation," Biotechnology and Bioengineering, vol. 75, no. 6, pp. 741-744, 2001.
[54] M. Hamid, J. T. McCluskey, N. H. McClenaghan, and P. R. Flatt, "Culture and function of electrofusion-derived clonal insulin-secreting cells immobilized on solid and macroporous microcarrier beads," Bioscience Reports, vol. 20, no. 3, pp. 167-176, 2000.

[55] P. Gupta, L. Geris, F. P. Luyten, and I. Papantoniou, “An integrated bioprocess for the expansion and chondrogenic priming of human periosteum-derived progenitor cells in suspension bioreactors," Biotechnology Journal, vol. 13, no. 2, article 1700087, 2018.

[56] J. L. Wilson and T. C. McDevitt, "Stem cell microencapsulation for phenotypic control, bioprocessing, and transplantation," Biotechnology and Bioengineering, vol. 110, no. 3, pp. 667-682, 2013.

[57] M. Mota, J. A. Teixeira, and A. Yelshin, "Immobilized particles in gel matrix-type porous media. Homogeneous porous media model," Biotechnology Progress, vol. 17, no. 5, pp. 860-865, 2001.

[58] B. L. Strand, A. E. Coron, and G. Skjak-Braek, "Current and future perspectives on alginate encapsulated pancreatic islet," Stem Cells Translational Medicine, vol. 6, no. 4, pp. 1053 1058, 2017.

[59] D. Pipeleers and B. Keymeulen, "Boost for alginate encapsulation in beta cell transplantation," Trends in Endocrinology \& Metabolism, vol. 27, no. 5, pp. 247-248, 2016.

[60] D. Freimark, P. Pino-Grace, S. Pohl et al., "Use of encapsulated stem cells to overcome the bottleneck of cell availability for cell therapy approaches," Transfusion Medicine and Hemotherapy, vol. 37, no. 2, pp. 3-73, 2010.

[61] S. Sart, S. N. Agathos, Y. Li, and T. Ma, "Regulation of mesenchymal stem cell 3D microenvironment: from macro to microfluidic bioreactors," Biotechnology Journal, vol. 11, no. 1, pp. 43-57, 2016.

[62] N. A. Silva, J. Moreira, S. Ribeiro-Samy et al., "Modulation of bone marrow mesenchymal stem cell secretome by ECM-like hydrogels," Biochimie, vol. 95, no. 12, pp. 2314-2319, 2013.

[63] E. C. Stucky, R. S. Schloss, M. L. Yarmush, and D. I. Shreiber, "Alginate micro-encapsulation of mesenchymal stromal cells enhances modulation of the neuro-inflammatory response," Cytotherapy, vol. 17, no. 10, pp. 1353-1364, 2015.

[64] V. Vaithilingam, M. D. M. Evans, D. M. Lewy, P. A. Bean, S. Bal, and B. E. Tuch, "Co-encapsulation and cotransplantation of mesenchymal stem cells reduces pericapsular fibrosis and improves encapsulated islet survival and function when allografted," Scientific Reports, vol. 7, no. 1, article 10059, 2017.

[65] S. Jung, K. M. Panchalingam, R. D. Wuerth, L. Rosenberg, and L. A. Behie, "Large-scale production of human mesenchymal stem cells for clinical applications," Biotechnology and Applied Biochemistry, vol. 59, no. 2, pp. 106-120, 2012.

[66] M. M. Bonab, K. Alimoghaddam, F. Talebian, S. H. Ghaffari, A. Ghavamzadeh, and B. Nikbin, "Aging of mesenchymal stem cell in vitro," BMC Cell Biology, vol. 7, no. 1, p. 14, 2006.

[67] S. Bork, S. Pfister, H. Witt et al., "DNA methylation pattern changes upon long-term culture and aging of human mesenchymal stromal cells," Aging Cell, vol. 9, no. 1, pp. 54-63, 2010.

[68] A. Stolzing, N. Coleman, and A. Scutt, "Glucose-induced replicative senescence in mesenchymal stem cells," Rejuvenation Research, vol. 9, no. 1, pp. 31-35, 2006. 
[69] M. R. Kreke and A. S. Goldstein, "Hydrodynamic shear stimulates osteocalcin expression but not proliferation of bone marrow stromal cells," Tissue Engineering, vol. 10, no. 5-6, pp. 780-788, 2004.

[70] F. Zhao, R. Chella, and T. Ma, "Effects of shear stress on 3-D human mesenchymal stem cell construct development in a perfusion bioreactor system: experiments and hydrodynamic modeling," Biotechnology and Bioengineering, vol. 96, no. 3, pp. 584-595, 2007.

[71] F. G. Teixeira, K. M. Panchalingam, R. Assunção-Silva et al., "Modulation of the mesenchymal stem cell secretome using computer-controlled bioreactors: impact on neuronal cell proliferation, survival and differentiation," Scientific Reports, vol. 6 , no. 1, article 27791, 2016.

[72] C. Elseberg, J. Leber, T. Weidner, and P. Czermak, "The challenge of human mesenchymal stromal cell expansion: current and prospective answers," in New Insights Into Cell Culture Technology, INTECH, Rijeka, Croatia - EUROPEAN UNION.

[73] A. C. Schnitzler, A. Verma, D. E. Kehoe et al., "Bioprocessing of human mesenchymal stem/stromal cells for therapeutic use: current technologies and challenges," Biochemical Engineering Journal, vol. 108, pp. 3-13, 2016.

[74] C. J. Hewitt, K. Lee, A. W. Nienow, R. J. Thomas, M. Smith, and C. R. Thomas, "Expansion of human mesenchymal stem cells on microcarriers," Biotechnology Letters, vol. 33, no. 11, pp. 2325-2335, 2011.

[75] M. Serra, C. Brito, M. F. Q. Sousa et al., "Improving expansion of pluripotent human embryonic stem cells in perfused bioreactors through oxygen control," Journal of Biotechnology, vol. 148, no. 4, pp. 208-215, 2010.

[76] V. Jossen, C. Schirmer, D. Mostafa Sindi et al., "Theoretical and practical issues that are relevant when scaling up hMSC microcarrier production processes," Stem Cells International, vol. 2016, Article ID 4760414, 15 pages, 201615 pages, 2016.

[77] G. Pattappa, H. K. Heywood, J. D. Bruijnde, and D. A. Lee, "The metabolism of human mesenchymal stem cells during proliferation and differentiation," Journal of Cellular Physiology, vol. 226, no. 10, pp. 2562-2570, 2011.

[78] C. Weber, D. Freimark, R. Pörtner et al., "Expansion of human mesenchymal stem cells in a fixed-bed bioreactor system based on non-porous glass carrier - Part B: modeling and scale-up of the system," The International Journal of Artificial Organs, vol. 33, no. 11, pp. 782-795, 2010.

[79] T. A. Grein, J. Leber, M. Blumenstock et al., "Multiphase mixing characteristics in a microcarrier-based stirred tank bioreactor suitable for human mesenchymal stem cell expansion," Process Biochemistry, vol. 51, no. 9, pp. 1109-1119, 2016.

[80] R. Olmer, A. Lange, S. Selzer et al., "Suspension culture of human pluripotent stem cells in controlled, stirred bioreactors," Tissue Engineering Part C: Methods, vol. 18, no. 10, pp. 772-784, 2012.

[81] C. Weber, S. Pohl, R. Poertner et al., "Production process for stem cell based therapeutic implants: expansion of the production cell line and cultivation of encapsulated cells," Advances in Biochemical Engineering/Biotechnology, vol. 123, pp. 143162, 2010.

[82] P. Czermak, R. Pörtner, and A. Brix, "Special engineering aspects," in Cell and Tissue Reaction Engineeringpp. 83-172, Springer Berlin Heidelberg, Berlin, Heidelberg.
[83] C. Weber, D. Freimark, R. Pörtner et al., "Expansion of human mesenchymal stem cells in a fixed-bed bioreactor system based on non-porous glass carrier - Part A: inoculation, cultivation, and cell harvest procedures," The International Journal of Artificial Organs, vol. 33, no. 8, pp. 512-525, 2010.

[84] M. J. Osiecki, T. D. Michl, B. Kul Babur et al., "Packed bed bioreactor for the isolation and expansion of placentalderived mesenchymal stromal cells," PLoS One, vol. 10, no. 12, article e0144941, 2015.

[85] C. Lechanteur, "Large-scale clinical expansion of mesenchymal stem cells in the GMP-compliant, closed automated quantum ${ }^{\circledR}$ cell expansion system: comparison with expansion in traditional T-flasks," Journal of Stem Cell Research \& Therapy, vol. 4, no. 08, 2014.

[86] A. Mizukami, A. Neto, M. S. de et al., "A fully-closed and automated hollow fiber bioreactor for clinical-grade manufacturing of human mesenchymal stem/stromal cells," Stem Cell Reviews and Reports, vol. 14, no. 1, pp. 141-143, 2018.

[87] M. Haack-Sørensen, B. Follin, M. Juhl et al., "Culture expansion of adipose derived stromal cells. A closed automated quantum cell expansion system compared with manual flask-based culture," Journal of Translational Medicine, vol. 14, no. 1, p. 319, 2016.

[88] T. Lambrechts, I. Papantoniou, B. Rice, J. Schrooten, F. P. Luyten, and J. M. Aerts, "Large-scale progenitor cell expansion for multiple donors in a monitored hollow fibre bioreactor," Cytotherapy, vol. 18, no. 9, pp. 1219-1233, 2016.

[89] A.-C. Tsai, Y. Liu, and T. Ma, "Expansion of human mesenchymal stem cells in fibrous bed bioreactor," Biochemical Engineering Journal, vol. 108, pp. 51-57, 2016.

[90] M. Guvendiren and J. A. Burdick, "Stiffening hydrogels to probe short- and long-term cellular responses to dynamic mechanics," Nature Communications, vol. 3, no. 1, article 792, 2012.

[91] S. Li, S. Kuddannaya, Y. J. Chuah, J. Bao, Y. Zhang, and D. Wang, "Combined effects of multi-scale topographical cues on stable cell sheet formation and differentiation of mesenchymal stem cells," Biomaterials Science, vol. 5, no. 10, pp. 2056-2067, 2017.

[92] H. Tanaka, S. Tanaka, K. Sekine et al., "The generation of pancreatic $\beta$-cell spheroids in a simulated microgravity culture system," Biomaterials, vol. 34, no. 23, pp. 5785-5791, 2013.

[93] G. J. Rogers, M. N. Hodgkin, and P. E. Squires, "E-cadherin and cell adhesion: a role in architecture and function in the pancreatic islet," Cellular Physiology and Biochemistry, vol. 20, pp. 987-994, 2007.

[94] A. C. Hauge-Evans, P. E. Squires, S. J. Persaud, and P. M. Jones, "Pancreatic beta-cell-to-beta-cell interactions are required for integrated responses to nutrient stimuli: enhanced $\mathrm{Ca} 2+$ and insulin secretory responses of MIN6 pseudoislets," Diabetes, vol. 48, no. 7, pp. 1402-1408, 1999.

[95] H. Ishihara, T. Asano, K. Tsukuda et al., "Pancreatic beta cell line MIN6 exhibits characteristics of glucose metabolism and glucose-stimulated insulin secretion similar to those of normal islets," Diabetologia, vol. 36, no. 11, pp. 1139-1145, 1993.

[96] M. J. Luther, A. Hauge-Evans, K. L. A. Souza et al., "MIN6 $\beta$ cell- $\beta$-cell interactions influence insulin secretory responses to nutrients and non-nutrients," Biochemical and Biophysical Research Communications, vol. 343, no. 1, pp. 99-104, 2006. 
[97] G. Niu, J. P. McQuilling, Y. Zhou, E. C. Opara, G. Orlando, and S. Soker, "In vitro proliferation of porcine pancreatic islet cells for $\beta$-cell therapy applications," Journal of Diabetes Research, vol. 2016, Article ID 5807876, 8 pages, 2016.

[98] P. Buchwald, "FEM-based oxygen consumption and cell viability models for avascular pancreatic islets," Theoretical Biology and Medical Modelling, vol. 6, no. 1, p. 5, 2009.

[99] B. A. Wagner, S. Venkataraman, and G. R. Buettner, "The rate of oxygen utilization by cells," Free Radical Biology and Medicine, vol. 51, no. 3, pp. 700-712, 2011.

[100] K. K. Papas, A. Pisania, H. Wu, G. C. Weir, and C. K. Colton, "A stirred microchamber for oxygen consumption rate measurements with pancreatic islets," Biotechnology and Bioengineering, vol. 98, no. 5, pp. 1071-1082, 2007.

[101] W. Wang, L. Upshaw, D. M. Strong, R. P. Robertson, and J. Reems, "Increased oxygen consumption rates in response to high glucose detected by a novel oxygen biosensor system in non-human primate and human islets," Journal of Endocrinology, vol. 185, no. 3, pp. 445-455, 2005.

[102] Z. Li, H. Sun, J. Zhang, H. Zhang, F. Meng, and Z. Cui, "Development of in vitro 3D TissueFlex ${ }^{\circledR}$ islet model for diabetic drug efficacy testing," PLoS One, vol. 8, no. 8, article e72612, 2013.

[103] J. Daoud, L. Rosenberg, and M. Tabrizian, "Pancreatic islet culture and preservation strategies: advances, challenges, and future outlook," Cell Transplantation, vol. 19, no. 12, pp. 1523-1535, 2010.

[104] L. P. Rutzky, S. Bilinski, M. Kloc et al., "Microgravity culture condition reduces immunogenicity and improves function of pancreatic islets1," Transplantation, vol. 74, no. 1, pp. 13-21, 2002.

[105] H. E. Murray, M. B. Paget, and R. Downing, "Preservation of glucose responsiveness in human islets maintained in a rotational cell culture system," Molecular and Cellular Endocrinology, vol. 238, no. 1-2, pp. 39-49, 2005.

[106] L. Samuelson and D. A. Gerber, "Improved function and growth of pancreatic cells in a three-dimensional bioreactor environment," Tissue Engineering Part C: Methods, vol. 19, no. 1, pp. 39-47, 2013.

[107] M. Mel, M. I. A. Karim, S. A. M. Yusuf, Y. Z. H.-Y. Hashim, and Y. Ahmad Nor, "Comparing BRIN-BD11 culture producing insulin using different type of microcarriers," Cytotechnology, vol. 62, no. 5, pp. 423-430, 2010.

[108] M. Chawla, C. A. Bodnar, A. Sen, M. S. Kallos, and L. A. Behie, "Production of islet-like structures from neonatal porcine pancreatic tissue in suspension bioreactors," Biotechnology Progress, vol. 22, no. 2, pp. 561-567, 2006.

[109] L. T. Lock, S. G. Laychock, and E. S. Tzanakakis, "Pseudoislets in stirred-suspension culture exhibit enhanced cell survival, propagation and insulin secretion," Journal of Biotechnology, vol. 151, no. 3, pp. 278-286, 2011.

[110] C. A. Hoesli, M. Luu, and J. M. Piret, "A novel alginate hollow fiber bioreactor process for cellular therapy applications," Biotechnology Progress, vol. 25, no. 6, pp. 1740-1751, 2009.

[111] S. I. Gundersen, G. Chen, H. M. Powell, and A. F. Palmer, "Hemoglobin regulates the metabolic and synthetic function of rat insulinoma cells cultured in a hollow fiber bioreactor," Biotechnology and Bioengineering, vol. 107, no. 3, pp. 582592, 2010.

[112] N. Nikravesh, S. C. Cox, M. J. Ellis, and L. M. Grover, "Encapsulation and fluidization maintains the viability and glucose sensitivity of beta-cells," ACS Biomaterials Science \& Engineering, vol. 3, no. 8, pp. 1750-1757, 2017.

[113] F. W. Pagliuca and D. A. Melton, "How to make a functional $\beta$-cell,” Development, vol. 140, no. 12, pp. 2472-2483, 2013.

[114] L. Goers, P. Freemont, and K. M. Polizzi, "Co-culture systems and technologies: taking synthetic biology to the next level," Journal of the Royal Society, Interface, vol. 11, no. 96, p. 20140065, 2014.

[115] S. J. Bidarra, C. C. Barrias, M. A. Barbosa, R. Soares, J. Amédée, and P. L. Granja, "Phenotypic and proliferative modulation of human mesenchymal stem cells via crosstalk with endothelial cells," Stem Cell Research, vol. 7, no. 3, pp. 186-197, 2011.

[116] A. Pisania, G. C. Weir, J. J. O'Neil et al., “Quantitative analysis of cell composition and purity of human pancreatic islet preparations," Laboratory Investigation, vol. 90, no. 11, pp. 1661-1675, 2010.

[117] F. A. Saleh, M. Whyte, and P. G. Genever, "Effects of endothelial cells on human mesenchymal stem cell activity in a three-dimensional in vitro model," European Cells and Materials, vol. 22, pp. 242-257, 2011.

[118] Y. Tachida, H. Sakurai, and J. Okutsu, "Proteomic comparison of the secreted factors of mesenchymal stem cells from bone marrow, adipose tissue and dental pulp," Journal of Proteomics \& Bioinformatics, vol. 8, no. 12, 2015. 


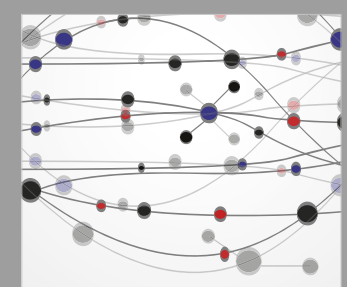

The Scientific World Journal
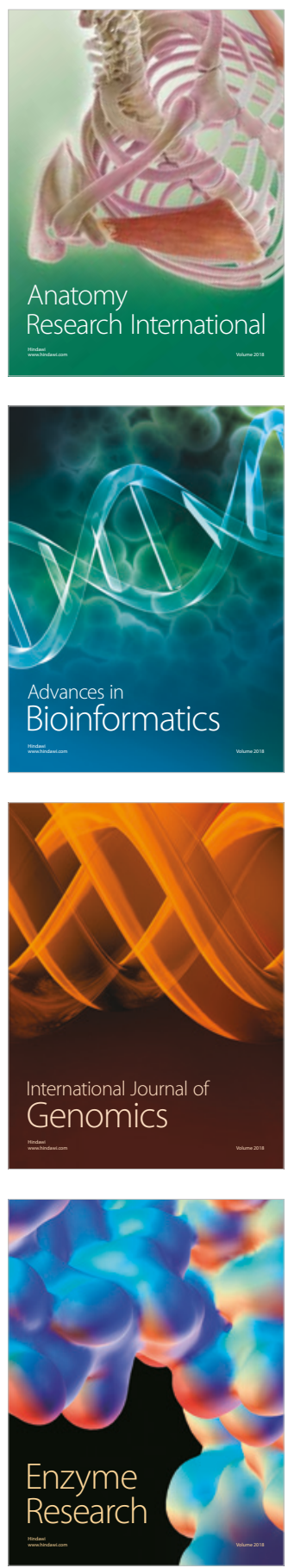
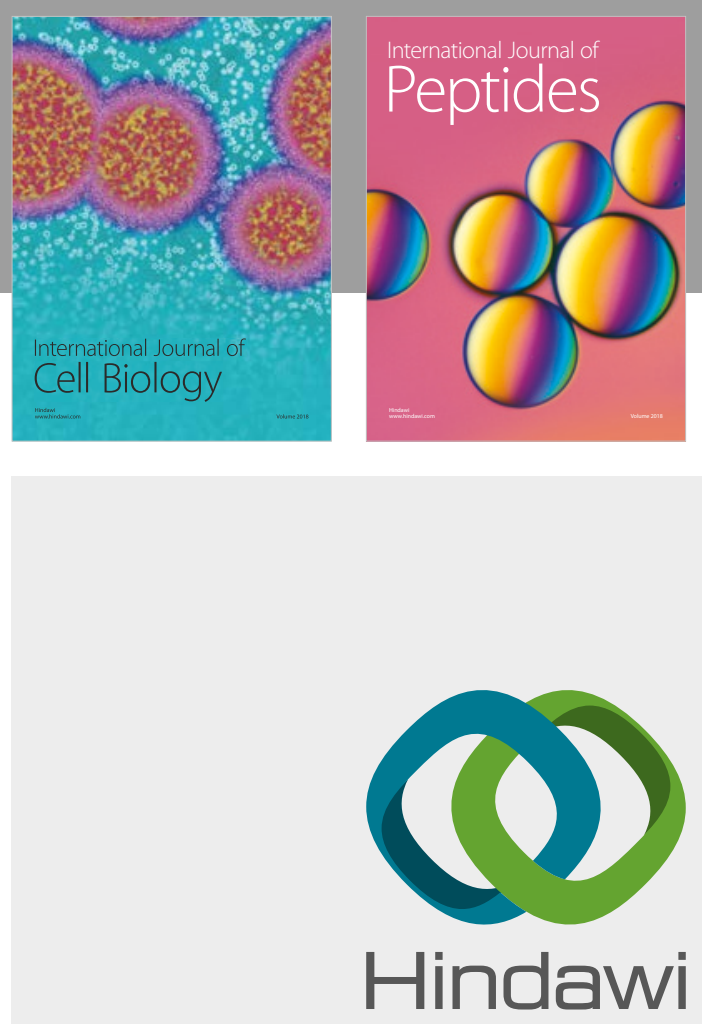

Submit your manuscripts at

www.hindawi.com
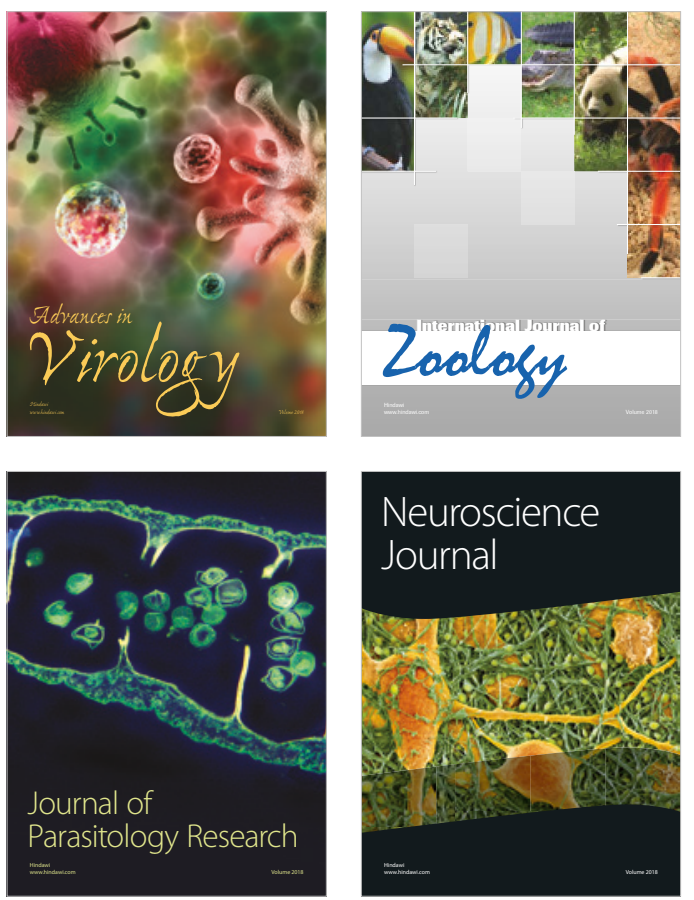
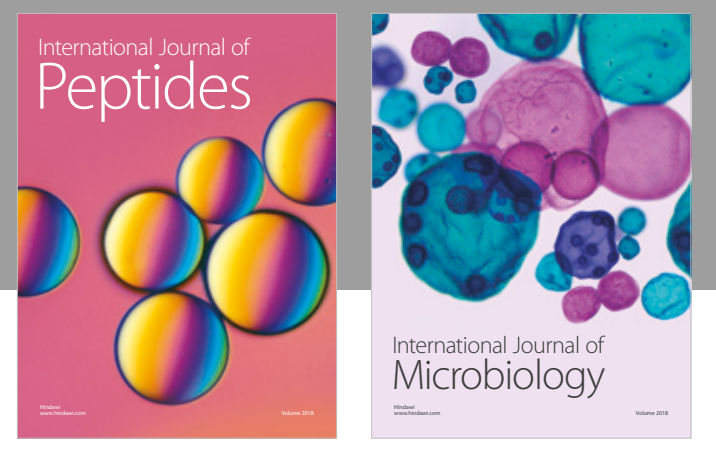

nternational Journal of Microbiology
Journal of
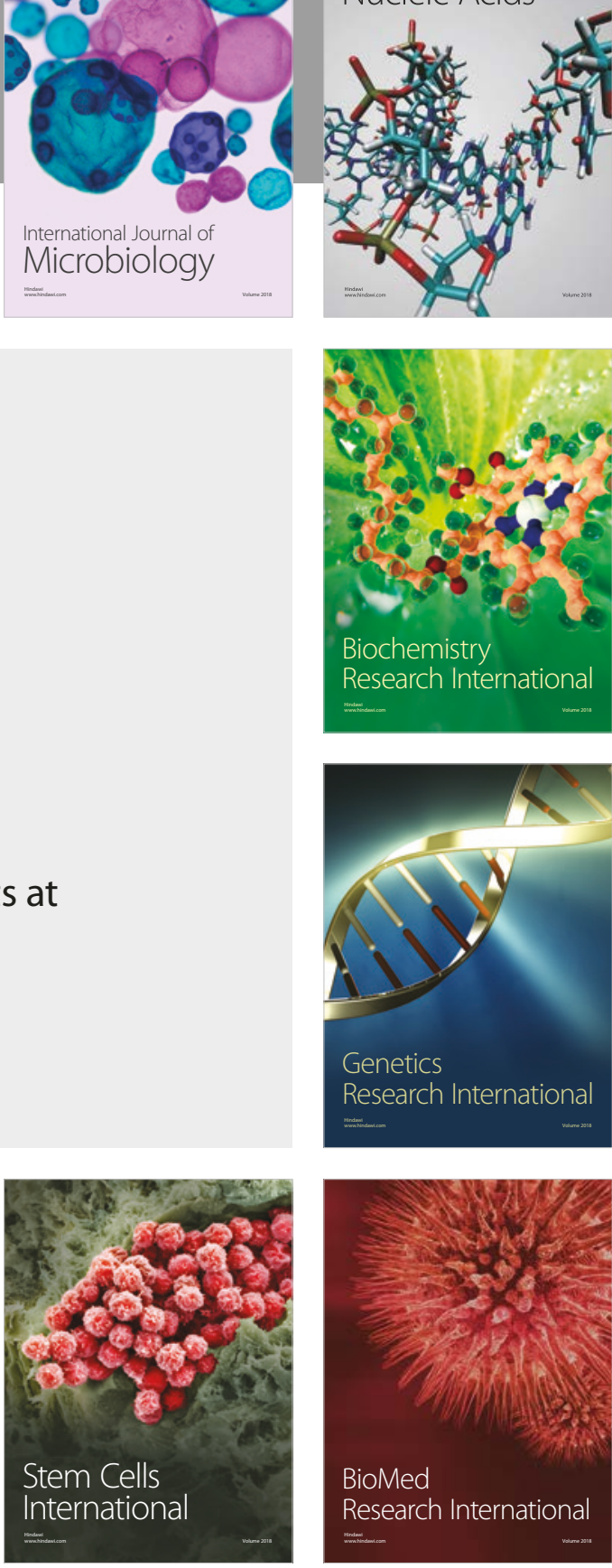
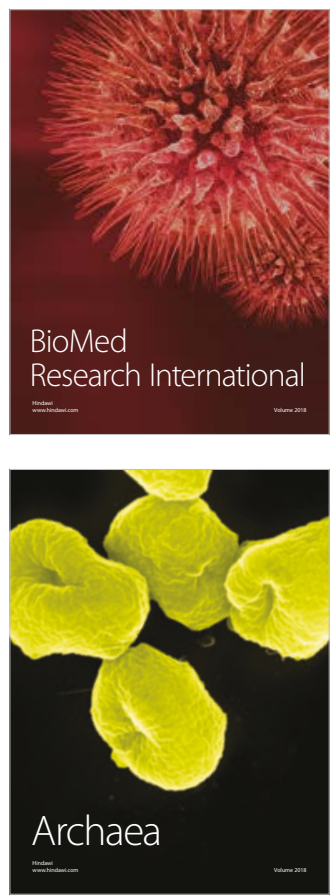